\section{Childhood Leukemia in the Vicinity of Nuclear Power Plants in Germany}

by Dr. rer. physiol. Peter Kaatsch, PD Dr. rer. nat. Claudia Spix, Irene Jung, Prof. Dr. rer. nat. Maria Blettner in volume 42/2008 and additional radiation exposure through nuclear power stations is implausible. If this conclusion has been clear from the beginning, I don't understand why the study was conducted in the first place.

After the leukemia increase that was found, the usual dose estimate in children now needs to be questioned. And this is where ignorance is a curse. This is part of the highly complex area of biodosimetry and dosage equivalents, a highly technical terrain that neither a psychologist and occupational scientist (Professor Jungermann) nor an epidemiologist and informatics specialist (Dr Kaatsch) is qualified to comment on. The normal, extremely arbitrary dose estimates would need to be subjected to highly complicated tests. Finally, research would need to be conducted into what radiation load exactly an individual resident in the vicinity of a nuclear power plant receives, not only via environmental radiation but also via environmental air and the food chain; how the biological distribution in the body tissues works over time; and which bone seeking radionuclides administer which dosage to a child's bone marrow. These questions would be worth studying and the computation models prestented by the German Commission on Radiological Protection would be worth verifying, and any insider knows exactly how very arbitrary the presented dose estimates are. What we do not need is a philosophical discourse about risk perception, nor repetitive emphasis on implausible causal associations compared with environmental radiation. What is required is careful checking of the dose estimates presented (allegedly only $1 / 1000$ of environmental radiation). The studies required for this would have to conduct laborious nuclide measurements in the biotope and in the environmental air that the children breathe over the long term.

The bone marrow of children who died due to leukemia in the vicinity of nuclear power plants would need to be compared in terms of its radionuclide uptake with that of children elsewhere. For knowledge to be interpreted and integrated, this knowledge has to be gained first of all!

DOl: 10.3238/arztebl.2009.0392b

\section{REFERENCES}

1. Kaatsch P, Spix C, Jung I, Blettner M: Childhood Leukemia in the Vicinity of Nuclear Power Plants in Germany. Dtsch Arztebl Int 2008; 105: 725-32.

Dr. med. Benno Splieth

Streuweg 100, 63755 Alzenau, Germany

eva.kopel@vital-klinik.de

\section{Against All Logic}

The article is factually inaccurate and misleading. The summary says: "The question whether leukemia rates are increased near nuclear power plants is controversial." This statement is not correct. It is scientifically proven that the number of cancers and leukemias in children is 
higher the closer they live to a nuclear power plant. The authors themselves have provided proof with their extraordinarily laborious study. The statement that the causes of the cancers are unknown is equally misleading. In the context of the study, causes other than emissions from nuclear power plants were excluded. It was investigated whether the cancers were due to pesticides or other possible confounders. But no such confounder was found.

The Epidemiological Study on Childhood Cancer in the Vicinity of Nuclear Power Plants (KiKK Study) explicitly investigated a causal association between radioactivity from nuclear power stations and cancers. This is the unequivocal message of a 2006 publication from the Mainz childhood cancer registry. The study methods state that the individual distance of the residence of the children with cancer was used as a substitute for individual radiation exposure.

In our opinion it contradicts any logic that the authors retrospectively exclude this part of the study design and thus do not accept their own findings. We therefore wish to ask for whose benefit the study was conducted. At least such a "chiseled" interpretation helps to keep nuclear power stations running.

DOl: 10.3238/arztebl.2009.0393a

\section{REFERENCES}

1. Kaatsch P, Spix Cet al.: Umweltforschungsplan des Bundesumweltministeriums, Vorhaben StSch 4334. Epidemiologische Studie zu Kinderkrebs in der Umgebung von Kernkraftwerken, Zusammenfassung, $\mathrm{Xl}$.

2. Grosche B, Jung T, Weiss W: Häufigkeit von Krebs bei Kindern in der Umgebung von Kernkraftwerken. atomwirtschaft Nr. 3/2008, 174-78.

3. Schulze-Rath R, Kaatsch P, Schmiedel S, Spix C, Blettner M: Krebs bei Kindern in der Umgebung von Kernkraftwerken: Bericht zu einer laufenden epidemiologischen Studie. Umweltmed Forsch Prax 2006; 11 : 23 (2.4).

4. Kaatsch P, Spix C, Jung I, Blettner M: Childhood Leukemia in the Vicinity of Nuclear Power Plants in Germany. Dtsch Arztebl Int 2008; 105: 725-32.

Dr. med. Angelika Claußen

Körtestr. 10

10967 Berlin, Germany

Reinhold Thie

Hölderlinstr. 23

89171 Illerkirchberg, Germany

\section{Children Are Very Sensitive to Radiation}

As a pediatrician I wish to point out children's extreme sensitivity to radiation. The younger a child, the quicker it will be damaged even by low grade radiation. This is the key to understanding the results of the Epidemiological Study on Childhood Cancer in the Vicinity of Nuclear Power Plants (KiKK Study). On this basis, we urgently demand that permitted emissions should be adjusted to the risk for an embryo.

The reasons for the extreme radiation sensitivity in children include:

- Growth means a high rate of cell division in all organ systems. Cell division is the risky phase for radiation damage; an embryo grows at an almost explosive rate. Its cells are constantly dividing, which is why even tiny amounts of radiation are extremely hazardous.

- The repair mechanisms that our organism uses to identify and eliminate mutated cells are not yet effective in children, especially in unborn children.

- Children have a positive substance balance-in order to thrive they have to consume more than they excrete, in contrast to adults who merely have to maintain their fully grown bodies. The positive balance in children leads to a prolonged biological half life in incorporated radioactive isotopes.

- Malignancies have a long latency period; in pathologies caused by radioactivity, decades may lie between exposure and detectable onset of illness. Children have their lives ahead of them; in contrast to older people, they may have the misfortune of experiencing the end of the latency period.

DOl: 10.3238/arztebl.2009.0393b

\section{REFERENCES}

1. Kaatsch P, Spix C, Jung I, Blettner M: Childhood Leukemia in the Vicinity of Nuclear Power Plants in Germany. Dtsch Arztebl Int 2008; 105: 725-32.

Dr. med. Winfrid Eisenberg

Wellbrocker Weg 61

32051 Herford, Germany

w.eisenberg@gmx.de

\section{Confusion About Childhood Cancer Study}

With their article, the authors are obviously attempting to play down the startling results of their own study. In the evaluation of data at the community level, the results from the Epidemiological Study on Childhood Cancer in the Vicinity of Nuclear Power Plants (KiKK Study), which found a notable increase in the leukemia risk in the vicinity of German nuclear power plants of $119 \%$, shrunk to an unremarkable, non-significant $41 \%$. The authors state that the discrepancy between the results is essentially due to the fact that the KiKK study accurately determined the distances between the childrens' homes and the next nuclear power plant while the ecological study uses community midpoints. . But the authors also say that both statements actually reflect different perspectives, and hence, both statements are correct. In a sense we should be grateful to the authors for conducting this additional ecological study. It demonstrates that ecological studies are much less able to detect regional clusters than more elaborate case-control studies. When the authors refer to the results of a recent study from England that, in contrast to the KiKK study, has not shown a leukaemia increase in the vicinity of nuclear power stations, it has to be borne in mind that this study, again, is an ecological study. In England, eighteen cases of leukemia were counted in a $5 \mathrm{~km}$ radius, only about half as many as in the KiKK study. The leukemia risk there in the $5 \mathrm{~km}$ radius was about $50 \%$ higher than in the adjacent 5-10 km zone, but, due to small case numbers, the increase was not significant. Although the English 
results are remarkably consistent with the German results, the authors conclude that there was no proof that acute leukemias are more common in the vicinity of nuclear power plants in England.

D0I: 10.3238/arztebl.2009.0394a

\section{REFERENCES}

1. Kaatsch P, Spix C, Jung I, Blettner M: Childhood Leukemia in the Vicinity of Nuclear Power Plants in Germany. Dtsch Arztebl Int 2008; 105: 725-32.

\section{Dr. rer. nat. Alfred Körblein}

Untere Söldnersgasse 8

90403 Nürnberg, Germany

alfred.koerblein@gmx.de

\section{In Reply:}

The correspondence reflects a part of the wide range of comments that were discussed in the context of our study on nuclear power stations, which was published in international and national peer reviewed journals $(1,2,3)$. The aspects presented are therefore not offering us new perspectives. It is important to point out that the statement in the correspondence from the IPPNW-stating that causes other than emissions from nuclear power stations could be eliminated in our study - is based on a misunderstanding. As we have shown repeatedly, we were technically not able to analyze potential factors of influence in our study. There is a fundamental difference between saying that the influence of certain factors cannot be evaluated or that certain factors can be eliminated. In the 2006 study cited by IPPNW (4), we already said that our study cannot be used to investigate general risk factors. It may be true that children have a different sensitivity to radiation than adults. It therefore makes sense to question the existing, approved calculation models for dose estimates and maybe replace these with better models. We are therefore grateful that the German Radiation Protection Commission with its wide expertise on radiation biology and physiology deals with these questions (5)—prompted by our study to no small degree. The suggestion of one correspondent—namely, to examine the bone marrow of children who died from leukemia near power stations-seems attractive but must thankfully fail because of the very low case numbers: in the $5 \mathrm{~km}$ radius of the 16 nuclear power plants we studied, 37 leukemias in children younger than 15 occurred over 24 years. Generally, about one fourth of the children die from their leukemia. To conduct such a study, no more than 4 children would be available for the next 10 years-if they all participated. For more detailed information on our study we refer to the detailed documentation from the German Commission on Radiological Protection, which was published in February 2009.

DOl: 10.3238/arztebl.2009.0394b

\section{REFERENCES}

1. Kaatsch P, Spix C, Schulze-Rath R, Schmiedel S, Blettner M: Leukaemia in young children living in the vicinity of German nuclear power plants. Int J Cancer 2008; 122: 721-6.

2. Spix C, Schmiedel S, Kaatsch P, Schulze-Rath R, Blettner M: Casecontrol study on childhood cancer in the vicinity of nuclear power plants in Germany 1980-2003. Eur J Cancer 2008; 44: 275-84.

3. Kaatsch P, Spix C, Jung I, Blettner M: Childhood Leukemia in the Vicinity of Nuclear Power Plants in Germany. Dtsch Arztebl Int 2008 105: 725-32.

4. Schulze-Rath R, Kaatsch P, Schmiedel S, Spix C, Blettner M: Krebs bei Kindern in der Umgebung von Kernkraftwerken: Bericht zu einer laufenden epidemiologischen Studie. Umweltmed Forsch Prax 2006; 11 : 20-6.

5. Strahlenschutzkommission (SSK): Bewertung der epidemiologischen Studie zu Kinderkrebs in der Umgebung von Kernkraftwerken (KiKKStudie). Berichte der Strahlenschutzkommission, Heft 57. www.ssk.de/werke/volltext/2008/ssk0806.pdf, 2008

Dr. rer. physiol. Peter Kaatsch

Institut für Medizinische Biometrie, Epidemiologie

und Informatik

Universitätsmedizin

55101 Mainz, Germany

kaatsch@imbei.uni-mainz.de

\section{Conflict of interest statement}

The authors of the letters and of the reply declare that no conflict of interest exists according to the guidelines of the International Committee of Medical Journal Editors. 